\title{
Psychological Approaches for Building up a Monologue-Story
}

\section{Психологічні підходи до побудови монологу-розповіді}

\section{Inna Nohachevska}

Ph.D. in Psychology, Assistant Professor, Rivne State University of the Humanities, Rivne (Ukraine)

ORCID ID: https://orcid.org/0000-0002-1489-6878

Researcher ID: http://www.researcherid.com/rid/AAL-7233-2021

E-mail: innatella@gmail.com

\section{Інна Ногачевська}

Кандидат психологічних наук, доцент, Рівненський державний гуманітарний університет, м. Рівне (Україна)

\section{Oksana Lohvina}

Ph.D. in Psychology, Assistant Professor, Kamianets-Podilskyi National Ivan Ohiienko University, Kamianets-Podilskyi (Ukraine)

ORCID ID: https://orcid.org/0000-0002-0359-5850

E-mail: oksanalogvina19@gmail.com

\section{Оксана Логвіна}

Кандидат психологічних наук, доцент, Кам'янець-Подільський національний університет імені Івана Огієнка, м. Кам'янецьПодільський (Україна)

The author's contribution: Nohachevska I. - 50\%, Lohvina O. - 50\%. Авторський внесок: Ногачевська І. - 50\%, Логвіна О. - 50\%.

Address for correspondence, e-mail: kpnu_lab_ps@ukr.net Copyright: (C) Nohachevska Inna, Lohvina Oksana

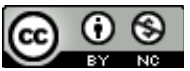
The article is licensed under CC BY-NC 4.0 International (https://creativecommons.org/licenses/by-nc/4.0/)

(C) Nohachevska Inna, Lohvina Oksana

DOI (article): https://doi.org/10.32626/2227-6246.2021-52.204-224 http://journals.uran.ua/index.php/2227-6246 


\section{ABSTRACT}

The purpose of this article is to define the communicative functions which monologue speech performs; to describe the characteristics of monologue speech; to show psychological approaches for building up a monologue-story.

The following theoretical methods of the research were used to solve the tasks formulated in the article: a categorical method, structural and functional methods, the methods of the analysis, systematization, modeling, generalization.

The results of the research. We distinguish the main psychological approaches which help pupils to understand English texts. The first one is the approach of Hermeneutics. It sees in the interpretation of the subject perceiving the novel, which is based on the imagination and intuition of the recipient, which allows him / her not only to reveal the author's idea, but also to feel the process of creating the text. General theoretical backgrounds of hermeneutics and the approach to understanding as the actualization of reflection will be presented in our further articles. The process of understanding how to build meanings occurs by actualizing reflection, the most important source of the person's experience that allows a person to improve his / her personality.

The next approach is psycho-linguistic. We proved that the comprehension of the text was directly connected with the understanding of the person's speech. We formulated the main aspects, which in subsequent psycholinguistic and cognitive studies were explained in the following aspects: 1) the activity basis of speech, such as its extralingual characteristics; 2) internal speech or universal subject code; 3) the concept of meaning and significance.

Conclusions. The main for building up a monologue-story is a cognitive approach. The defining feature of the cognitive approach for the study of comprehension was the position that language was only a small part of the holistic phenomenon that speakers are trying to learn. The process of cognition is based on the complex interactions of memory processes, physiological characteristics of a man, his / her knowledge of the world, the social context of utterances, ways of interaction of all the activities of the individual in general and the organization of all types of knowledge in particular.

The cognitive approach characterizes two main factors: 1) shifting the attention of researchers from the object (a text) to the subject ("Me - the speaker»; "Me - the listener»; "Me - the reader»); 2) shift of the person's attention from clearly identified micro-units, which are considered in isolation, to units with a high degree of complexity. In the first case, the understanding of speech

(C) Nohachevska Inna, Lohvina Oksana DOI (article): https://doi.org/10.32626/2227-6246.2021-52.204-224 
DOI: https://doi.org/10.32626/2227-6246.2021-52

2021. випуск 52

is considered as a constructive activity of the subject, carried out on the basis of his / her knowledge; in the second one, involving more complex units for comprehension analysis instead of relatively simple messages. Accordingly, along with the text, the object of the activity, we try actively studying the subjects-speakers (listeners / readers) processes.

The movement from meaning to sense determines the very process of understanding, in which we identify several integrated stages that have semantic independence: a psychophysiological perception of a physical sign (a word, color, spatial form); a recognition of meaning (as "a friend» or "a stranger»); understanding its recurring (general) meaning in language; understanding its significance in the specified context (near or far); active-dialogic understanding (agreement-disagreement), such as the evaluative moment in understanding.

Key words: monologue speech, psychological approaches, Hermeneutics, psycho-linguistic approach, cognitive approach, psychophysiological perception, a recognition of meaning, active-dialogic understanding.

\section{Introduction}

Nowadays, at secondary school the teaching of monologue speech is not always given enough attention. This position is erroneous, because it is this aspect of learning that disciplines thinking, teaches to think logically and accordingly build pupils' statements in such a way as to «bring» their thoughts to the listener.

Communication in its oral form, mastering which is one of the main tasks of learning a foreign language at school for practical purposes, is carried out through listening and speaking. The teacher who transmits information to others performs the action of speaking, and all who listen to him / her perform the act of listening. Oral communication, which is carried out in one-sided speech, when one person speaks with a detailed statement, and the other one - only perceives his / her speech, then such oral speech acquires a monologue form. Extended statements during monologue speech are based on the internal logic of the development of the speaker's thoughts and on the context of the whole statement, taking into account the situation of communication.

(C) Nohachevska Inna, Lohvina Oksana

DOI (article): https://doi.org/10.32626/2227-6246.2021-52.204-224 http://journals.uran.ua/index.php/2227-6246 
Monologue speech is a coherent continuous statement of one person, addressed to one or more partners. The purpose of such a statement is usually the need to influence other people in some way, to convince them with something. Monologue speech is closely related to dialogic speech. Most often, a monologue is a special case of dialogic speech, when the statement of one of the partners is presented in an expanded form as a complete message. Therefore, during studying the person's speech, the monologue form is a further development of detailed utterances in the system of a dialogical speech (Cilibrasi, Stojanovik, Riddell \& Saddy, 2019).

Pupils begin detailed monologue utterances only when they master the language material in dialogic exercises to the extent necessary for the organization of monologue utterances based on different grammatical structures. Pupils learn monologue utterances, larger in volume, at the stage when they have already accumulated sufficient language material and they are able to use it freely in oral form. This allows pupils to pay full attention to the logical sequence of phrases when they are expressing their own opinion in a foreign language.

One of the main tasks of teaching monologue speech is the development of oral language skills. The ability to understand spoken language and express one's thought is necessary for many people; this is due to the growing of political, economic, cultural ties between our country and many other countries all around the world.

A monologue is an organized type of oral speech with the aim directly influence on the partner of communication or the audience, which involves the utterance of one person. Monologue speech is characterized by certain communicative, psychological and linguistic features that the teacher has to take into account in the process of learning this type of speech activity (Гончарук \& Онуфрієва, 2018).

So, the purpose of this article is to define the communicative functions which monologue speech performs; to describe

(C) Nohachevska Inna, Lohvina Oksana DOI (article): https://doi.org/10.32626/2227-6246.2021-52.204-224 
DOI: https://doi.org/10.32626/2227-6246.2021-52

2021. виПУСК 52

the characteristics of monologue speech; to show psychological approaches for building up a monologue-story.

\section{Methods of the research}

The following theoretical methods of the research were used to solve the tasks formulated in the article: a categorical method, structural and functional methods, the methods of the analysis, systematization, modeling, generalization.

\section{Results and their discussion}

Monologue speech performs the following communicative functions:

1) the informative one - the message of information about objects or events of the environment, a description of phenomena, actions, conditions;

2) the influential function - the incitement to the action or prevention of undesirable action, belief in the justice or injustice of certain views, opinions, actions, beliefs;

3) the expressive (emotionally expressive) one - the use of communication to describe the state in which the speaker is to relieve emotional tension;

4) the entertaining function - a performance of a person on stage or among friends to entertain the audience (for example, art reading, storytelling in an informal conversation);

5) the function of ritual-cult - the utterances during any ritual rite (Brédart, 1991).

Each of these functions has its own specific linguistic means of the expression, appropriate psychological stimuli and the purpose of the expression (for example, stylistically neutral message, a desire to persuade the listener or in some other way to influence him).

Monologue speech has the following characteristics:

1) a coherence, which distinguishes monologue speech from a random set of sentences and it is considered in two aspects psychological and linguistic ones. In the first case it is about (C) Nohachevska Inna, Lohvina Oksana

DOI (article): https://doi.org/10.32626/2227-6246.2021-52.204-224 
DOI: https://doi.org/10.32626/2227-6246.2021-52

2021. випуск 52

the coherence of thoughts, which is expressed in the compositional and semantic unity of the text as a product of speech, in the second case - it is about the coherence of speech, which involves the possession of linguistic means of interphrase communication;

2) theme-related characteristic, as the correlation of the statement with a general theme. Monologue utterance has a certain communicative and semantic organization. First of all, it clearly states the presence of a certain topic, which, in turn, is divided into a number of subtopics or microthemes;

3) contextuality, which should not be contrasted with situationality - a characteristic feature of a dialogic speech. A monologue can also be situational (for example, a spontaneous utterance is an expanded cue) (in some cases, a monologue can be visually situational (for example, in a movie, TV show);

4) a relatively continuous flow of speech. The monologue is usually not limited to one phrase and lasts for a certain time without interruption, thus achieving completeness of thoughts;

5) consistency and logic. These qualities of monologue speech are realized in the development of the idea of the main phrase by clarifying the idea, supplementing it, explaining, justifying, etc. (Mykhalchuk \& Bihunova, 2019).

The state educational standard in a foreign language (general secondary education) provides for pupils' language mastering the following types of monologue: a short message, a story, a reflection (persuasion). Proper attitude to foreign monologue speech at the middle stage of learning makes it possible to use a foreign language as a means of communication at the lessons, in particular in the process of explaining and consolidating new lexical and grammatical material.

At the middle stage of learning a foreign language monologue, the teacher has to set himself / herself the following tasks:

- to pay enough attention to pupils' mastery of monologue speech;

(C) Nohachevska Inna, Lohvina Oksana DOI (article): https://doi.org/10.32626/2227-6246.2021-52.204-224 
DOI: https://doi.org/10.32626/2227-6246.2021-52

2021. випуск 52

- to teach schoolchildren to formulate a monologue using an active lexical vocabulary;

- to organize training in monologue speech correctly;

- to cope with the difficulties that arise before pupils in the process of mastering monologue speech;

- to teach to build independently and coherently their own statements;

- to evaluate objectively this type of speech activity.

In the educational process which is carried out by a foreign language teacher, there is a continuous flow of speech situations that can and should be used with a purpose to communicate with a foreign language. Mastering the monologue language at the secondary stage of learning causes certain difficulties, which also exist in the native language - it is the simultaneous implementation of semantic and language programs. In order to be able clearly and coherently to build his / her statement for a pupil, who speaks, this speech in a whole is pronounced without destructive, the process of communication stops between sentences, there must be intonation bias of the next sentence with the pronunciation of the previous one. It is not easy to formulate a monologue for other reasons as well: for example, limited program material; limited time of communication in a foreign language; individual characteristics of pupils and teachers (Crookes, 1989).

Thus, monologue speech, which is taught for adolescents at foreign language lessons at school, is a common statement that has its own theme and idea and is characterized by communicative, psychological and linguistic features that the teacher has taken into account in learning, as well as structural completeness, completeness of expressions, completeness of speech in general.

A monologue-narrative is a type of a monologue speech, which is defined as a coherent continuous statement of one person addressed to one or more partners of communication. The purpose of such a statement is usually the need to influ(C) Nohachevska Inna, Lohvina Oksana

DOI (article): https://doi.org/10.32626/2227-6246.2021-52.204-224 
ence other pupils in some a way, to tell something new, interesting, etc.

The varieties of a monologue-story are: a monologue-description and a monologue-message. If the story is about objective facts from the life of the society as a whole, then the description is about the facts from the life of the narrator, which shows the described events, subjective and personal nature. A monologue-message is a relatively brief account of the facts or events of the reality in a concise, informative form.

The monologue-story uses non-linguistic means of communication. In some cases, they have only an ancillary value. Instead of them, the monologue-narrative is characterized by contextuality, it must be clear for understanding. Insufficiency of out-of-order means of communication and limitation of communicative functions of a situation is compensated here by the development of structure of sentences, building logical communications between them. The text of the monologue-story should say everything that is obvious from the situation.

A characteristic feature of the monologue-story is the ability to plan statements (programming), which leads to a clearer sequence and logic of the material. The peculiarity of teaching a monologue-story of teenagers is that it can be thought out and prepared, therefore, it is easier to learn.

An important role in learning a monologue-story is played by the speech situation. Learning speech situation is an effective means of developing skills and abilities of monologue speech. It creates for pupils imaginary conditions close to the conditions of a real communication. This helps to increase pupils' interests in learning a language, as they are convinced that they can realize their language potential in an act of communication close to natural one.

In the process of learning speech situation, everyone can activate the lexical and grammatical material in such a way that it plays a role in building a monologue-story, which will contribute to its better mastery.

(C) Nohachevska Inna, Lohvina Oksana

DOI (article): https://doi.org/10.32626/2227-6246.2021-52.204-224 
DOI: https://doi.org/10.32626/2227-6246.2021-52

2021. випуск 52

Pupils learn about the imagination with the help of studying speech situations. The teacher constantly creates imaginary situations in which pupils are happy to perform the roles offered to them. They are also aware of and perceive the conventionality of speech situations.

The monologue-narrative is characterized by a theme and an idea which determine its composition, sequence and logical expressions of thoughts. The formation of skills of a monologue speech is connected with intensive activity of the person's memory. It is necessary to teach pupils to adhere to the logical harmony of the monologue.

The monologue-narrative is characterized by linguistic means of interphrase communication. Adverbs of time and sequence, conjunctions, pronoun repetitions in a great degree become connecting elements of sentences (then, so, after that, presently, before long, to make the long story short, in the end, that's how, that's what, to crown it all; but, also, besides, then again, as you see, on the one(other) hand, for one thing, firstly, secondly, thirdly, moreover, after all, for all that, to sum it up).

While mastering other subjects, pupils gain experience of a monologue speech in their native language, but their statements are directed on the teacher and the textbook material. At foreign language lessons pupils should build independent statements based on their life experience, knowledge, preferences, beliefs, which require a systematic approach.

Learning a monologue-story is done by gradually bringing pupils to the construction of unprepared statements. Schoolchildren can perform various roles (class guests, correspondents, newspaper or television reporters), solving communicative tasks related to a monologue speech (prepared or unprepared) of other pupils. The teacher should organize the practice in monologue speech with the help of conditional-communicative and communicative types of exercises. Stages of learning to build a monologue-story should be correlated with (c) Nohachevska Inna, Lohvina Oksana

DOI (article): https://doi.org/10.32626/2227-6246.2021-52.204-224 
certain stages of the activity on the thematic cycle - pre-text (preparatory), text and post-text (speech).

It would seem that a group conversation has nothing to do with a monologue-story, but it is characterized by signs of a monologue speech. Statements of some pupils are connected in it by rules of construction of a dialogue where language clichés and various types of dialogic units are used. At the same time, pupils' statements can be so detailed that they should be considered as story-monologues.

Group conversations can be carried out starting from the 8th form, when pupils have formed the necessary foreign language skills, accumulated experience in speaking a foreign language, developed intellectual abilities, have some life experience, achieved a certain level of literacy in native and foreign languages. These exercises require from schoolchildren a certain level of intellectual development, developed their attention, the ability to start a conversation in time, logically include their own story into a general context of a conversation.

The teacher should prepare pupils for a group conversation: organizes exercises in monologue speech with a certain speech reaction of those who listen to the teacher or other partners of communication, submits appropriate language clichés.

In the process of communication such types of group conversation as interview, discussion and round table conversation are most often used. The easiest type of group conversation is to learn an interview, which begins learning a conversation that is closely related to a monologue-story. This connection is traced in the preparation of a schoolchild for the interview: the teacher helps to select interesting information, learn new words which need to be presented before the conversation (Mykhalchuk \& Ivashkevych, 2019).

Participating in the discussion, pupils move away from the pre-prepared, memorized, begin to express their personal opinions. At this time, consciousness completely switches to the subject of the discussion, to its content. Schoolchildren 
may experience a lack of language skills, in which case they interrupt speaking, asking the teacher for help, who should suggest pupils how to use well learned vocabulary, to express an opinion.

A monologue-story during the discussion will be successful only if it is properly organized. It is important to find an interesting subject for the discussion (characters of novels, their actions, thoughts, as well as the author's reasoning). It can be organized on the basis of a conversational topic. For example, while learning vocabulary on the topic of «Travelling» (the $8^{\text {th }}$ form), the teacher can suggest a topic of discussion «The best and most interesting way to travel».

Having chosen the problem for discussion, the teacher should acquaint the pupils with it in advance, invite them to express their attitude to it and justify their own views. For several days, schoolchildren reflect on their position and arguments. Before the conversation begins, the teacher finds out who and what opinion he / she will defend, for what he / she can use the cards on which pupils will write whether they agree with a certain opinion or not (I agree, I don't agree). The teacher should collect the cards and place the pupils in such a way that the teams of «like-minded» sit opposite each other, and he / she should sit between them and regulate the process of the discussion.

It is advisable to start the conversation with the "weakest» pupils so that they can make the most of the story prepared in advance. At first, two or three schoolchildren who share the same views speak. Pupils who hold a different opinion, listen and receive tasks (listen and give your counter-arguments). The teacher should praise pupils for activity and independence of thinking, express an opinion on the problem having been discussed.

An important role in teaching a foreign language monologue-story of teenagers is played by such a group conversation as a round table discussion - a group exchange of views on the (c) Nohachevska Inna, Lohvina Oksana

DOI (article): https://doi.org/10.32626/2227-6246.2021-52.204-224 
topic being studied or dates or holidays approaching, seen a movie, play, book read, exhibition visited, etc. Pupils should sit in a circle and see each other during the conversation. At the previous lesson the teacher, having thought out a plan for a future conversation, should give specific tasks to schoolchildren: what to prepare, where to get the necessary information.

At the lesson during the round table discussion the teacher should sit in a circle with pupils, announce the topic of conversation, describe the range of issues for the discussion and prepare each schoolchild individually for the conversation. Firstly, pupils exchange prepared stories, and then gradually move on to the conversation, where the prepared speeches of some pupils stimulate the unprepared speech of others. In $a$ round table discussion teenagers learn to build detailed monologues-stories, logically and consistently reveal their thoughts, show their attitude to the event.

Thus, the monologue-narrative is an active productive type of monologue speech. Learning a monologue-story is done by gradually bringing pupils to the construction of unprepared statements. The teacher should organize the practice in monologue speech with the help of conditional-communicative and communicative types of exercises. The complexities of the monologue-story is in its detailed, logical, consistent structure and coherence of the elements of the text. Learning a foreign monologue-story involves firstly the formation of stories that consists of simple sentences of the same type, then - the creation of their own monologues.

In such a way we distinguish the main psychological approaches which help pupils to understand English texts. The first one is the approach of Hermeneutics. It sees in the interpretation of the subject perceiving the novel, which is based on the imagination and intuition of the recipient, which allows him / her not only to reveal the author's idea, but also to feel the process of creating the text. General theoretical backgrounds of hermeneutics and the approach to understanding as

(C) Nohachevska Inna, Lohvina Oksana DOI (article): https://doi.org/10.32626/2227-6246.2021-52.204-224 
DOI: https://doi.org/10.32626/2227-6246.2021-52

2021. випуск 52

the actualization of reflection will be presented in our further articles. The process of understanding how to build meanings occurs by actualizing reflection, the most important source of the person's experience that allows a person to improve his / her personality.

We understand this process as the method of interpretive type, which is based on the statement that hermeneutics - it is the science of understanding texts and, at the same time - the activity of understanding. In hermeneutics the verbal aspect of understanding is seen as the art of finding the hidden meaning in the text in the direction from understanding to explanation, and vice versa. It is the science not so much of the means of comprehending the directly perceived text as of the hidden interrelationships and determinants that form a more general context, and through the disclosure of which the directly perceived one becomes clear. Hermeneutics remains the most theoretically developed concept of studying the personified product of human creativity - it is the text.

The next approach is psycho-linguistic one. It studies the comprehension of the text which is directly connected with the understanding of the person's speech. We formulated the main aspects, which in subsequent psycholinguistic and cognitive studies were explained in the following aspects: 1) the activity basis of speech, such as its extralingual characteristics; 2) internal speech or universal subject code; 3 ) the concept of meaning and significance.

Understanding in Psychology is one of the cognitive processes, which is the disclosure of really existing, essential connections of objects and phenomena of objective reality. Psycholinguistic approaches to understanding the text as a process that takes place during the interaction of perception, thinking and memory, actualizes the word as a significant linguistic unit, and the process of perception itself which is carried out by establishing semantic connections between words.

(c) Nohachevska Inna, Lohvina Oksana

DOI (article): https://doi.org/10.32626/2227-6246.2021-52.204-224 
DOI: https://doi.org/10.32626/2227-6246.2021-52

2021. випуск 52

We, as the proponents of the psycholinguistic approach consider understanding as the construction of a text projection. At the same time, according to the national tradition (Максименко, Ткач, Литвинчук \& Онуфрієва, 2019), the text is interpreted as an approximate basis of complex and multifaceted mental activity of the active and biased subject of this activity, which occurs under the interaction of memory, thinking, inner speech, etc. Within this direction, the understanding of the text is as a hierarchy of predicates or a hierarchy of informative-target blocks having been studied on the level of macro- and microstructure of the text, which differ in speech acts of people. For example, we note that the main pattern of understanding the text is the ability of information to collapse, in the process of which it is translated into internal speech. At the same time, the highest degree of understanding of the message is characterized by the ability of the subject to freely express the information he / she understands in his / her own words, and this is possible only if the perceived information is translated into the internal code of the recipient.

\section{Conclusions}

The main for building up a monologue-story is a cognitive approach. The defining feature of the cognitive approach for the study of comprehension was the position that language is only a small part of the holistic phenomenon that speakers are trying to learn. The process of cognition is based on the complex interactions of memory processes, physiological characteristics of a man, his / her knowledge of the world, the social context of utterances, ways of interaction of all the activities of the individual in general and the organization of all types of knowledge in particular.

The cognitive approach characterizes two main factors: 1) shifting the attention of researchers from the object (a text) to the subject ( $\mathrm{Me}$ - the speaker»; «Me - the listener»; «Me the reader»); 2) shift of the person's attention from clearly

(C) Nohachevska Inna, Lohvina Oksana DOI (article): https://doi.org/10.32626/2227-6246.2021-52.204-224 
DOI: https://doi.org/10.32626/2227-6246.2021-52

2021. випуск 52

identified micro-units, which are considered in isolation, to units with a high degree of complexity. In the first case, the understanding of speech is considered as a constructive activity of the subject, carried out on the basis of his / her knowledge; in the second one, involving more complex units for comprehension analysis instead of relatively simple messages. Accordingly, along with the text, the object of the activity, we try actively studying the subjects-speakers (listeners / readers) processes.

In the paradigm of cognitive theory the problems of text comprehension are reflected in symbolic (symbolic), hybrid (integrative) models of text comprehension. We, as the proponents of the cognitive approach consider understanding as the construction of a mental model of the world. A model is a construct in episodic memory that represents the event or a situation referred to in the whole text. Different sources are used to construct such models of situations, as: knowledge about language, knowledge about the world in general and about a specific communicative situation. The personal experience of the reader is added to a common knowledge. When reading different texts, the recipient applies specific strategies which are necessary to understand the features of the poem, rhythm, organizational principles of the activity, etc., while understanding literary texts is associated with emotional experience and aesthetic experience of the reader.

The review of the main aspects of the problem of text comprehension in Cognitive Linguistics makes us possible to identify a new range of problems which are important for text comprehension in Psychology, such as: a study of communicative features of the subject in the process of understanding poetic text, a study of thesaurus organization of linguistic personality, a study of the process of obtaining information from the text of the author and its transfer to the text of the recipient. The dialogical nature of understanding is realized through the leading concept in any theory of understanding, and the (C) Nohachevska Inna, Lohvina Oksana

DOI (article): https://doi.org/10.32626/2227-6246.2021-52.204-224 
main in this case is the meaning. The category of meaning in contemporary researches serves as the starting point for the universalization of the procedure of understanding. To reveal the essence of the category helps the opposition "the meaning the sense», which are characterized by the language, by any cultural activity.

The movement from meaning to sense determines the very process of understanding, in which we identify several integrated stages that have semantic independence: a psychophysiological perception of a physical sign (a word, color, spatial form); a recognition of meaning (as «a friend» or «a stranger»); understanding its recurring (general) meaning in language; understanding its significance in the specified context (near or far); active-dialogic understanding (agreement - disagreement), such as the evaluative moment in understanding.

Thus, according to our theory of a monologue speech, understanding is a movement from the meaning of a recognizable object, a text: from repeated and reproduced, the actual semantic side of the text, the external form of a culture - to the meaning that is always personalized, dialogical, which involves the experience, a sense of the activity, the evaluation.

\section{Literature}

Гончарук Наталія, Онуфрієва Ліана. Психологічний аналіз рівнів побудови комунікативних дій. Psycholinguistics. Психолінгвістика. Психолингвистика. 2018. Вип. 24 (1). С. 97-117. DOI 10.31470/ 2309-1797-2018-24-1-97-117.

Максименко С., Ткач Б., Литвинчук Л., Онуфрієва Л. Нейропсихолінгвістичне дослідження політичних гасел із зовнішньої реклами. Psycholinguistics. Психолінгвістика. Психолингвистика. Переяслав-Хмельницький : ФОП Домбровська Я. М., 2019. Вип. 26 (1). C. 246-264. DOI 10.31470/2309-1797-2019-26-1-246-264. URL : https://psycholing-journal.com/index.php/journal/article/ view/715.

Brédart, S. (1991). Word interruption in self-repairing. Journal of Psycholinguistic Research. Vol. 20. P. 123-137. URL : https://doi.org/ $10.1007 / \mathrm{bf} 01067879$.

(C) Nohachevska Inna, Lohvina Oksana

DOI (article): https://doi.org/10.32626/2227-6246.2021-52.204-224 
DOI: https://doi.org/10.32626/2227-6246.2021-52

2021. ВИПУСК 52

Cilibrasi, L., Stojanovik, V., Riddell, P., \& Saddy, D. (2019). Sensitivity to Inflectional Morphemes in the Absence of Meaning: Evidence from a Novel Task. Journal of Psycholinguist Research. Vol. 48. P. 747-767. URL : https://doi.org/10.1007/s10936-019-09629-y.

Crookes, G. (1989). Planning and interlanguage variation. Studies in Second Language Acquisition. Vol. 11. P. 367-383. URL : https://doi. org $/ 10.1017 / \mathrm{s} 0272263100008391$.

Mykhalchuk, N., \& Bihunova, S. (2019). The verbalization of the concept of «fear» in English and Ukrainian phraseological units. Cognitive Studies |Études cognitives, Vol. 19. Р. 11. Варшава (Польща). URL : https://doi.org/10.11649/cs.2043.

Mykhalchuk, N., \& Ivashkevych, E. Psycholinguistic Characteristics of Secondary Predication in Determining the Construction of a Peculiar Picture of the World of a Reader. Psycholinguistics. Психолінгвістика. Психолингвистика. Переяслав-Хмельницький : ФОП Домбровська Я. М., 2019. Вип. 25 (1). С. 215-231. DOI 10.31470/ 2309-1797-2019-25-1-215-231.

\section{References}

Honcharuk, Nataliia, \& Onufriieva, Liana (2018). Psykholohichnyi analiz rivniv pobudovy komunikatyvnykh dii [Psychological analysis of the levels of construction of communicative actions]. Psycholinguistics. Psykholinhvistyka. Psikholingvistika - Psycholinguistics. Psycholinguistics. Psycholinguistics, 24 (1), 97-117. Pereiaslav-Khmelnytskyi : FOP Dombrovska Ya. M. DOI 10.31470/2309-1797-2018-24-1-97117 [in Ukrainian].

Maksymenko, S., Tkach, B., Lytvynchuk, L., \& Onufriieva, L. (2019). Neiropsykholinhvistychne doslidzhennia politychnykh hasel iz zovnishnoi reklamy [A neuropsycholinguistic research of political slogans from outdoor advertising]. Psycholinguistics. Psykholinhvistyka. Psikholingvistika - Psycholinguistics. Psycholinguistics. Psycholinguistics, 26 (1), 246-264. Pereiaslav-Khmelnytskyi : FOP Dombrovska Ya. M. DOI 10.31470/2309-1797-2019-26-1-246-264 [in Ukrainian].

Brédart, S. (1991). Word interruption in self-repairing. Journal of Psycholinguistic Research, 20, 123-137. Retrieved from https://doi.org/ $10.1007 /$ bf01067879.

Cilibrasi, L., Stojanovik, V., Riddell, P., \& Saddy, D. (2019). Sensitivity to Inflectional Morphemes in the Absence of Meaning: Evidence from a Novel Task. Journal of Psycholinguist Research, 48, 747-767. Retrieved from https://doi.org/10.1007/s10936-019-09629-y.

(C) Nohachevska Inna, Lohvina Oksana

DOI (article): https://doi.org/10.32626/2227-6246.2021-52.204-224 
Crookes, G. (1989). Planning and interlanguage variation. Studies in Second Language Acquisition, 11, 367-383. Retrieved from https:// doi.org/10.1017/s0272263100008391.

Mykhalchuk, N., \& Bihunova, S. (2019). The verbalization of the concept of "fear» in English and Ukrainian phraseological units. Cognitive Studies | Études cognitive, 19, 11. Warsaw (Poland). Retrieved from https://doi.org/10.11649/cs.2043.

Mykhalchuk, N., \& Ivashkevych, E. (2019). Psycholinguistic Characteristics of Secondary Predication in Determining the Construction of a Peculiar Picture of the World of a Reader. Psycholinguistics. Psykholinhvistyka. Psikholingvistika - Psycholinguistics. Psycholinguistics. Psycholinguistics, 25 (1), 215-231. Pereiaslav-Khmelnytskyi : FOP Dombrovska Ya. M. DOI 10.31470/2309-1797-2019-25-1-215-231.

\section{Ногачевська Інна, Логвіна Оксана. Психологічні підходи до побудови мо-} нологу-розповіді

\section{АНОТАЦІЯ}

Мета статmі - визначити комунікативні функції, які виконує монологічне мовлення; описати характеристики монологічного мовлення; показати психологічні підходи до побудови монологу-розповіді.

Для розв'язання поставлених у роботі завдань використано такі теоретичні методи дослідження: категоріальний, структурно-функціональний, аналіз, систематизація, моделювання, узагальнення.

Результати дослідження. Ми розрізняємо певні психологічні підходи до побудови монологу-розповіді. Перший підхід є герменевтичним. Герменевтика вбачає в розумінні інтерпретацію людини, яка сприймає художній текст автора; в основі цього процесу покладено уяву й інтуїцію реципієнта, що дає змогу йому не лише розкрити задум автора, а й відчути процес створення тексту. Зазначено, що прочес розуміння як побудова смислів відбувається шляхом актуалізації рефлексії, найважливішого джерела досвіду, що дозволяє людині удосконалювати ії особистість.

Наступний напрямок є психолінгвістичним. Доведено, що цей напрямок дослідження розуміння тексту безпосередньо пов'язаний із розумінням мовлення. Сформульовано основні положення, які в подальших психолінгвістичних і когнітивних дослідженнях були експліковані в таких аспектах: 1) діяльнісна основа мовлення, тобто ії екстралінгвальні характеристики; 2) внутрішнє мовлення, або універсальний предметний код; 3) поняття значення й смислу.

(C) Nohachevska Inna, Lohvina Oksana DOI (article): https://doi.org/10.32626/2227-6246.2021-52.204-224 
Висновки. Показано, що для побудови монологу-розповіді базовим $\epsilon$ когнітивний підхід. Визначальною ознакою цього підходу стало положення про те, що мова є лише незначною частиною цілісного явища, яке співрозмовники намагаються пізнати. Процес пізнання відбувається на основі комплексної взаємодії процесів пам'яті, фрізіологічних властивостей людини, ії знань про світ, соціального контексту висловлювань, способів взаємодії всієї діяльності особистості загалом та організації всіх типів знань зокрема.

Когнітивний підхід характеризується двома основними чинниками: 1) зміщення уваги дослідників від об'єкта (тексту) до суб'єкта ("я - адресант»; "я-адресат»; "я-читач»); 2) зміщення уваги від чітко виявлених мікроодиниць, які розглядаються ізольовано, до одиниць, що вирізняються високим ступенем складності. У першому випадку розуміння мовлення розглядається як конструктивна діяльність суб'єкта, що здійснюється на основі його знань; у другому - як залучення складніших одиниць для аналізу розуміння замість порівняно простих повідомлень. Відповідно, поряд із текстом - об'єктом діяльності - слід також активно вивчати суб'єктів-адресантів (адресатів / читачів).

Визначено, що рух від значення до смислу визначає сам прочес розуміння, у якому ми виокремлюємо декілька інтегрованих етапів, що мають змістову самостійність: психофрізіологічне сприйняття фізичного знаку (слова, кольору, просторової форми); впізнання його (як знайомого чи незнайомого); розуміння його повторюваного (загального) значення в мові; розуміння його значення в певному контексті (найближчому чи далекому); активно-діалогічне розуміння (погодження - непогодження), тобто експлікація очіночного моменту в розумінні.

Ключові слова: монологічне мовлення, психологічні підходи, герменевтика, психолінгвістичний підхід, когнітивний підхід, психофізіологічне сприйняття, розпізнавання значення, активно-діалогічне розуміння.

\section{Ногачевская Инна, Логвина Оксана. Психологические подходы к пост- роению монолога-рассказа}

\section{АННОТАЦИЯ}

Цель статьи - определить коммуникативные функции, которые выполняет монологическая речь; описать характеристики монологической речи; показать психологические подходы к построению монолога-рассказа. (c) Nohachevska Inna, Lohvina Oksana

DOI (article): https://doi.org/10.32626/2227-6246.2021-52.204-224 
DOI: https://doi.org/10.32626/2227-6246.2021-52

2021. ВИПУСК 52

Для решения поставленных в работе задач использованы следующие теоретические методы исследования: категориальный, структурно-функциональный, анализ, систематизация, моделирование, обобщеHUe.

Результаты исследования. Мы различаем определенные психологические подходы к построению монолога-рассказа. Первый подход-герменевтический. Герменевтика видит в понимании интерпретацию человека, который воспринимает художественный текст автора; в основе этого процесса лежит воображение и интуиция реципиента, что позволяет ему не только раскрыть замысел автора, но и почувствовать процесс создания текста. Отмечено, что прочесс понимания как построение смыслов происходит путем актуализации рефлексии, важнейшего источника опыта, позволяющего человеку совершенствовать его личHOCMь.

Следующее направление является психолингвистическим. Доказано, что данное направление исследования понимания текста непосредственно связано с пониманием речи. Сформулированы основные положения, которые в дальнейших психолингвистических и когнитивных исследованиях были эксплицированы в следующих аспектах: 1) деятельностная основа речи, то есть ее экстралингвистические характеристики; 2) внутренняя речь, или универсальный предметный код; 3) понятие значения и смысла.

Выводы. Показано, что для построения монолога-рассказа базовым является когнитивный подход. Определяющим признаком данного подхода стало положение о том, что язык является лишь незначительной частью целостного явления, которое собеседники пытаются узнать. Процесс познания происходит на основе комплексного взаимодействия прочессов памяти, физиологических свойств человека, его знаний о мире, социального контекста высказываний, способов взаимодействия всей деятельности личности в целом и организации всех типов знаний в частности.

Когнитивный подход характеризуется двумя основными факторами: 1) смещение внимания исследователей от объекта (текста) к субъекту («я - адресант», «я-адресат», «я-читатель»); 2) смещение внимания от четко выявленных микроединии, которые рассматриваются изолированно, к единицам, которые отличаются высокой степенью сложности. В первом случае понимание речи рассматривается как кон-

(C) Nohachevska Inna, Lohvina Oksana DOI (article): https://doi.org/10.32626/2227-6246.2021-52.204-224 
DOI: https://doi.org/10.32626/2227-6246.2021-52

2021. випуск 52

структивная деятельность субъекта, осуществляемая на основе его знаний; во втором - как привлечение более сложных единиц для анализа понимания вместо сравнительно простых сообщений. Соответственно, наряду с текстом - объектом деятельности - следует также активно изучать субъектов-адресантов (адресатов / читателей).

Определено, что движение от значения к смыслу определяет сам процесс понимания, в котором мы выделяем несколько интегрированных этапов, имеющих смысловую самостоятельность: психофизиологическое восприятие физического знака (слова, ивета, пространственной формы); опознание его (как знакомого или незнакомого); понимание повторяющегося (общего) значения в языке; понимание его значения в определенном контексте (ближайшем или далеком); активно-диалогическое понимание (согласование - рассогласование), то есть экспликация оценочного момента в понимании.

Ключевые слова: монологическая речь, психологические подходы, герменевтика, психолингвистический подход, когнитивный подход, психофизиологическое восприятие, распознавание значения, активно-диалогическое понимание.

Original manuscript received February 26, 2021 Revised manuscript accepted April 16, 2021

(C) Nohachevska Inna, Lohvina Oksana

DOI (article): https://doi.org/10.32626/2227-6246.2021-52.204-224 http://journals.uran.ua/index.php/2227-6246 